\title{
Effects of Bacillus subtilis on Candida albicans: biofilm formation, filamentation and gene expression
}

Efeitos de Bacillus subtilis sobre Candida albicans: formação de biofilme, filamentação e expressão gênica

Michelle Peneluppi SILVA' ${ }^{1}$, Patrícia Pimentel de BARROS ${ }^{1}$, Adeline Lacerda JORJÃO ${ }^{1}$, Rodnei Dennis ROSSONI ${ }^{1}$, Juliana Campos JUNQUEIRA ${ }^{1}$, Antonio Olavo Cardoso JORGE ${ }^{1}$.

1 - Univ Estadual Paulista (Unesp) - Institute of Science and Technology, São José dos Campos - Department of Biosciences and Oral Diagnosis - São José dos Campos - SP - Brazil.

\section{ABSTRACT}

Objective: The aim of this study was evaluate the effect of Bacillus subtilis on Candida albicans biofilm formation and filamentation by evaluating the gene expression of ALS3, HWP1, BCR1, EFG1 and TEC1. Material and Methods: Mixed (C. albicans / B.subtilis) and monotypic biofilms were cultured in plates at $37^{\circ} \mathrm{C}$ for $48 \mathrm{~h}$ under shaking for counting viable cells ( $\mathrm{CFU} / \mathrm{mL}$ ) and analysis of gene expression by real-time PCR. The $C$. albicans filamentation assay was performed in medium containing $10 \%$ fetal bovine serum at $37^{\circ} \mathrm{C}$ for 6 hours. Data was analysed by $t$-Student and MannWhitney tests. Results: B. subtilis reduced the biofilm formation of C. albicans in $1 \log$ when cultured in the same environment $(\mathrm{p}<0.0001)$. In addition, it significantly reduced the yeast hypha transition

affecting the morphology of $C$. albicans. Among all of the analyzed genes, the ALS3 and HWP1 genes were the most affected, achieving 111.1- and 333.3fold decreases in the $C$. albicans biofilms associated with $B$. subtilis, respectively. Conclusion: B. subtilis reduced the biofilm formation and filamentation of C. albicans by negatively regulating the ALS3, HWP1, $B C R 1, E F G 1$ and TEC1 genes that are essential for the production of biofilm and hyphae.

\section{KEYWORDS}

Bacillus subtilis; Candida albicans; Biofilm; Filamentation; Gene expression.

\section{RESUIMO}

Objetivo: O objetivo deste estudo foi avaliar o efeito de Bacillus subtilis sobre a formação de biofilme e filamentação de Candida albicans através da avaliação da expressão dos genes ALS3, HWP1, BCR1, EFG1 and TEC1. Material e métodos: Biofilmes monotípicos e mistos (C. albicans / B.subtilis) foram cultivados em placas a $37^{\circ} \mathrm{C}$ por $48 \mathrm{~h}$ sob agitação, para a contagem de células viáveis (UFC/mL) e para a análise da expressão gênica por PCR em tempo real. O ensaio de filamentação de $C$. albicans foi realizado em meio contendo $10 \%$ de soro fetal bovino a $37^{\circ} \mathrm{C}$ por $6 \mathrm{~h}$. Os dados obtidos foram analisados por testes t-Student e Mann-Whitney. Resultados: B.subtilis reduziu em $1 \log$ a formação de biofilme por C. albicans quando cultivados no mesmo ambiente $(\mathrm{p}<0.0001)$. Além disso, reduziu significantemente a transição de levedura para hifa, afetando assim, a morfologia de C. albicans. Em relação aos genes analisados, os genes ALS3 e HWP1 foram os mais regulados negativamente, com uma diminuição de 111,1 e 333,3 vezes, respectivamente, na sua expressão em biofilmes de $C$. albicans associados a $B$. subtilis. Conclusão: $B$. subtilis reduziu a filamentação e a formação de biofilme de $C$. albicans através da regulação negativa dos genes ALS3, HWP1, BCR1, EFG1 e TEC1, que são essenciais na produção de hifas e de biofilme.

\section{PALAVRAS-CHAVE}

Bacillus subtilis; Candida albicans; Biofilme; Filamentação; Expressão gênica. 


\section{INTRODUCTION}

C andida albicans is a commensal fungus found on mucosal surfaces of the oral cavity, gastrointestinal and genitourinary tracts. This yeast causes severe and recurrent mucosal infections as well as fatal invasive infections in both immunocompromised and immunocompetent individuals [1].

Some virulence factors such as dimorphism and the ability to adhere and form biofilm on medical devices and/or the host mucosal epithelium, enhance the pathogenicity of $C$. albicans. The cells in biofilms exhibit distinct phenotypes that are similar to their free-living counterparts, including extreme resistance to many antimicrobial agents. Advances in genetic manipulation and expression profiling have helped define the regulatory pathways and mechanisms that govern C. albicans biofilm development $[1,2,3]$. Several classes of genes, such as specify transcription factors (EFG1, BCR1, TEC1) and adhesion (HWP1, ALS3), control biofilm development on abiotic and biotic surfaces [4,5].

In the recent past, microbial secondary metabolites have engrossed great attention of researchers as antifungal compounds. Most of the antifungal compounds currently in use are synthetic derivatives with known serious side effects and toxicity [6]. Emergence of drug resistant Candida has augmented the desire for new biocompatible antifungal drugs $[7,8]$.

The genus Bacillus includes a great diversity of industrially important strains, including Bacillus subtilis. This spore-forming bacterium has been established as industrial bacteria in the production of biological indicators for sterilization, in studies of biodefense and astrobiology methods as well as disinfection agents, in treatment evaluation and as potential adjuvants or vehicles for vaccines, among other applications. The metabolic diversity and lack of reported incidenceof pathogenicity makes this bacterium the most suitable for the development of marketable products [9].

Bacillus strains could produce some metabolites that inhibit pathogens, since some Bacillus species used in commercially available products have the ability to produce antimicrobials, such as aminocumaim A [10] and bacteriocin [11,12]. Zheng and Slavik [11] isolated and characterized a bacteriocin (molecular weight of approximately $34 \mathrm{kDa}$ and a pI value of approximately 47) of $B$. subtilis 22 . Firstly, the precipitated supernatant from the $B$. subtilis 22 culture had inhibitory activity in nine strains of Gram-negative and Gram-positive bacteria by agar diffusion assay. After partial purification of supernatant, the bacteriocin was named bacillocin 22 making this peptide potentially useful against the food-borne pathogens. In a recent study, Mayer and Kronstad [13] have identified the soil bacterium, Bacillus safensis, as a potent inhibitor of virulence factor production by two major fungal pathogens of humans, Cryptococcus neoformans, and C. albicans. They determined that the anti-virulence factor mechanism was, at least in part, baseded on production of bacterial chitinases that target and destabilize the fungal cell surface.

In this context, in an attempt to investigate new compounds and/or metabolites with antifungal properties produced by a sporulated bacillus, the current study was evaluate the effect of B. subtilis on C. albicans biofilm formation and filamentation by evaluating the gene expression of ALS3, HWP1, BCR1, EFG1 and TEC1.

\section{MATERIAL AND METHODS}

\section{Microorganisms and growth conditions}

In this study, we used the reference strains of B. subtilis (ATCC 19659) and C. albicans (ATCC 18804); these strains were plated on Brain Heart Infusion Agar (Difco, Detroit, USA) and Sabouraud Dextrose Agar (Difco, Detroit, USA), respectively, and were 
incubated at $37{ }^{\circ} \mathrm{C}$ for $24 \mathrm{~h}$. After growth, bacterial colonies were transferred and cultured in Brain Heart Infusion Broth (BHI) (Difco Laboratories Inc., Detroit, MI, USA) and the yeast in Yeast Nitrogen Base - YNB (Difco Laboratories Inc., Detroit, MI, USA) at $37{ }^{\circ} \mathrm{C}$ for $24 \mathrm{~h}$.

\section{Biofilm formation}

Suspensions of each microorganism sample were adjusted to $10^{7}$ cells $/ \mathrm{mL}$ using a spectrophotometer (B582, Micronal, São Paulo, Brazil). The formation of monotypic and mixed biofilms was based on the methodology described by Seneviratne et al. [14] and Bridier et al. [15] with modifications. Biofilms were formed in the bottom of a 96-well microtiter plate $(\mathrm{TPP} \AA$, Trasadingen, Switzerland), by pipetting $100 \mu \mathrm{L}$ of a standardized suspension containing $10^{7}$ cells $/ \mathrm{mL}$ of each microorganism, C. albicans and B. subtilis, associated in each well to the formation of a mixed biofilm. For monotypic biofilm formation, $100 \mu \mathrm{L}$ of only one microorganism and $100 \mu \mathrm{L}$ BHI broth were pipetted in each well. The plates were incubated under shaking at $75 \mathrm{rpm}$ rotation (Quimis, Diadema, Brazil) for $90 \mathrm{~min}$ at 37 ${ }^{\circ} \mathrm{C}$ with only the microorganisms to facilitate initial adhesion.

After adhesion phase, the suspension of non-adhered microorganisms was aspirated, and each well was washed with $200 \mu \mathrm{L}$ of $0.85 \% \mathrm{NaCl}$ to remove the non-adhered cells; $200 \mu \mathrm{L}$ of BHI broth was added in all formed biofilms, both monotypic and mixed groups. All plates were incubated at $37^{\circ} \mathrm{C}$ for $48 \mathrm{~h}$ under shaking at $75 \mathrm{rpm}$ rotation. After $24 \mathrm{~h}$, the broth was changed and after $48 \mathrm{~h}$, the biofilms were aspirated and washed with $0.85 \% \mathrm{NaCl}$ to remove the non-adhered cells. Biofilms were evaluated in relation to cell viability (quantification of the colony forming units $\mathrm{CFU} / \mathrm{mL}$ ) and gene expression in interspecies interaction. For each of these evaluations the experiment was performed in triplicate at two different times with 10 trials for each experimental group, resulting in 180 trials.

\section{$\mathrm{mL})$ \\ Quantification of viable cells (CFU/}

After washing the biofilm, $200 \mu \mathrm{L}$ of $0.85 \% \mathrm{NaCl}$ was added in each well for homogenization during $30 \mathrm{~s}$ in an ultrasonic homogenizer (Vibra Cell-Sonics \& Materials, Inc. Newtown, Connecticut, USA), with 25\% amplification to detach the biofilms. Serial dilutions of suspensions were performed, and $100 \mu \mathrm{L}$ aliquots of each dilution were plated in the culture medium, according to the microorganism: BHI Agar supplemented with fluconazole for B. subtilis and HiCrome Candida Differential Agar (Himedia, Mumbai, India) for C. albicans. The plates were incubated at $37^{\circ} \mathrm{C}$ for $48 \mathrm{~h}$ to count the $\mathrm{CFU} / \mathrm{mL}$ and converted into logarithm to base 10 ( $\mathrm{Log}$ ).

\section{C. albicans filamentation production}

The filamentation assay was performed in 24-well microtiter plates (TPP $®$, Trasadingen, Switzerland) following a methodology described previously with modifications [16]. The experimental groups formed were: $C$. albicans + PBS (Phosphate Buffered Saline) (control group) and C. albicans $+B$. subtilis (interaction group). After 18 hours of growth C. albicans and B. subtilis were centrifuged to prepare standard suspensions corresponding to $10^{7}$ cells $/ \mathrm{mL}$ in a spectrophotometer as previously described. In 24-well cell culture plates, $1 \mathrm{~mL}$ distilled water supplemented with $10 \%$ bovine fetal serum was added to a $100 \mu \mathrm{L}$ C. albicans suspension. Then, a $100 \mu \mathrm{L}$ $B$. subtilis suspension was added to each well. The control group used $100 \mu \mathrm{L}$ PBS.

The plate was incubated at $37^{\circ} \mathrm{C}$ for $6 \mathrm{~h}$ and $50 \mu \mathrm{L}$ of the inoculum contained in each well was placed on microscopic glass slides with 10 fields previously marked on the back and observed under an optical microscope with a magnification of $400 \mathrm{x}$. The images were analyzed in relation to $C$. albicans morphology and hyphae quantification in 10 microscopic fields per slide and classified as scores from 0 to 4 attributed to each field according to the number of hyphae present: 
score 0: no hyphae; score 1: 1 to 20 hyphae; score 2: 21 to 40 hyphae; score 3: 41 to 50 hyphae; and score 4: more than 50 hyphae. Each experimental group had 5 trials at two different times, totaling 20 tests. The percentage of germination was calculated considering the mixed group formed by $C$. albicans- B. subtilis in relation to monotypic group of $C$. albicans.

Evaluation of ALS3, HWP1, BCR1, EFG1 and TEC1 gene expression with qPCR

The evaluation of $C$. albicans virulence genes was based on the methodology described by Barros et al. [17] with modifications. Biofilms were formed in 24-well microtiter plates (TPP $®$, Trasadingen, Switzerland) with the same concentration and conditions as in the "Biofilm formation" section. The expression of ALS3, HWP1, BCR1, EFG1 and TEC1 genes was evaluated in relation to four reference genes, ACT1 ( $\beta$-Actin), RIP1 (Ubiquinol Cytochrome-c Reductase Complex Component), PMA1 (Adenosine Triphosphatase) and LSC2 (Succinyl-CoA Synthetase $\beta$-Subunit Fragment), described in the literature [18], in all experimental groups. The results were analyzed at http:// www.leonxie.com/referencegene.phpe, and the reference gene RIP1 was selected for this experiment.

Total RNA was extracted using the Trizol reagent (Ambion $®$, Carlsbad, USA), according to the manufacturer's recommendations. The purity, quality and concentration of the RNA were analyzed by the NanoDrop 2000 spectrophotometer (Thermo Fisher Scientific Inc., Wilmington, USA). To remove contaminating DNA, RNA $(1 \mu \mathrm{g})$ extracted was treated with DNase I (Turbo DNase Treatment and Removal Reagents - InvitrogenTM, Carlsbad, USA) and transcribed into complementary DNA (cDNA) using the SuperScript ${ }^{\mathrm{TM}}$ III First-Strand Synthesis Super Mix for qRT-PCR Kit with SYBR $® G r e e n$ (InvitrogenTM, Carlsbad, USA), according to the protocol recommended by the manufacturer.
Transcribed cDNA was amplified for the relative quantification of $A L S 3, H W P 1$, BCR1, EFG1 and TEC1 gene expression levels in relation to the concentration of the selected reference gene, RIP1. Quantitative real-time PCR was conducted using the Platinum ${ }^{\circledR}$ SYBR ${ }^{\circledR}$ Green qPCR SuperMixUDG Kit (Applied Biosystems, Framingham, MA, USA) in the StepOnePlus ${ }^{\mathrm{TM}}$ apparatus (Applied Biosystems, Framingham, MA, USA). The 2-DDCT method was used to analyze the relative changes in gene expression from the quantitative RT-qPCR experiment [19].

\section{Statistical analysis}

Student's $t$-test was used to compare the $\mathrm{CFU} / \mathrm{mL}$ results from the in vitro biofilm formation assay and the relative quantification of gene expression. The scores obtained from the filamentation analysis were compared using the Mann-Whitney test. All analyses were performed using the GraphPad Prism 5 Program (GraphPad Software, Inc., USA) and $5 \%$ level of signifcance was adopted.

\section{RESULTS}

The $\mathrm{CFU} / \mathrm{mL}$ count of $C$. albicans in monotypic biofilms showed higher values compared to mixed biofilms formed by associations between $C$. albicans and $B$. subtilis (Figure 1). Comparing the results obtained in monotypic biofilms with mixed biofilms, there was a reduction of $1.0 \log$ of $C$. albicans with a statistically significant difference ( $p$ $=0.001)$. B. subtilis was not affected in the mixed biofilm compared to monotypic ( $\mathrm{p}=$ 0.7002). The results, expressed in mean and standard deviation, for CFU/mL counts of $C$. albicans in monotypic biofilms were $5.38 \pm$ $0.149 \mathrm{log}$ and $4.37 \pm 0.183$ in mixed biofilms. For B. subtilis, the means were $5.33 \pm 0.202$ $\log$ in monotypic biofilms and $5.11 \pm 0.179$ in mixed biofilms.

In relation to the filamentation test, the results showed reduction of morphological transition (yeast/hyphae) for C. albicans in 
the presence of $B$. subtilis ( $C$. albicans and $B$. subtilis interaction), with a statistically significant reduction $(\mathrm{p}=0.0001)$ compared to the control group with PBS (Figure 2).

To elucidate the inhibitory mechanisms of $B$. subtilis on $C$. albicans biofilms, this study was extended to analyze $C$. albicans gene expression, concentrating on genes involved in biofilm formation and filamentation. The expression levels of the adhesion genes (ALS3 and $H W P 1$ ) and transcriptional regulatory genes (TEC1, BCR1 and EFG1) were quantifed in $C$. albicans cells from monotypic and mixed biofilms using qPCR. In $C$. albicans and $B$. subtilis association, ALS3, HWP1, BCR1, TEC1 and $E F G 1$ genes were downregulated when compared to the $C$. albicans control group with statistically significant differences $(\mathrm{p}=0.0001)$ (Figure 3 ). Among all of the analyzed genes, the ALS3 and HWP1 genes were the most affected, achieving 111.1- and 333.3-fold decreases in the $C$. albicans biofilms associated with $B$. subtilis, respectively. These results agreed with those obtained for the $\mathrm{CFU} / \mathrm{mL}$ counts and filamentation assay and suggest that $B$. subtilis exerts inhibitory effects on $C$. albicans by interfering with yeast adherence during biofilm formation and reducing its development during filamentation.

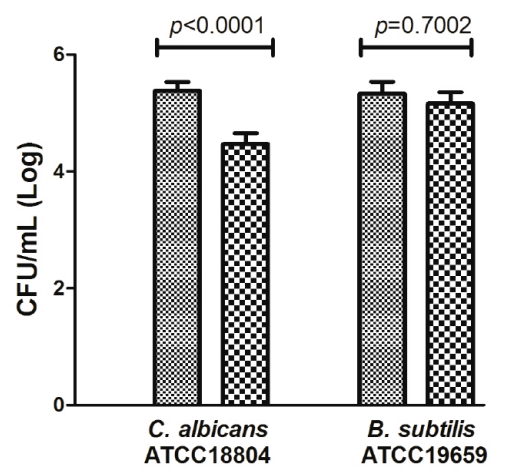

Single biofilm Q Mixed biofilm

Figure 1 - Quantitative analysis of in vitro biofilm formation by CFU/mL count: Means and standard deviations of $C$. albicans ATCC18804 and B. subtilis ATCC19659 CFU/mL (Log) values in the following groups: monotypic, formed by $C$. albicans (Control group); mixed, formed by C. albicans + B. subtilis, monotypic, formed by B.subtilis; mixed, formed by C. albicans $+B$. subtilis. Student's t-test, $p \leq 0.05$.
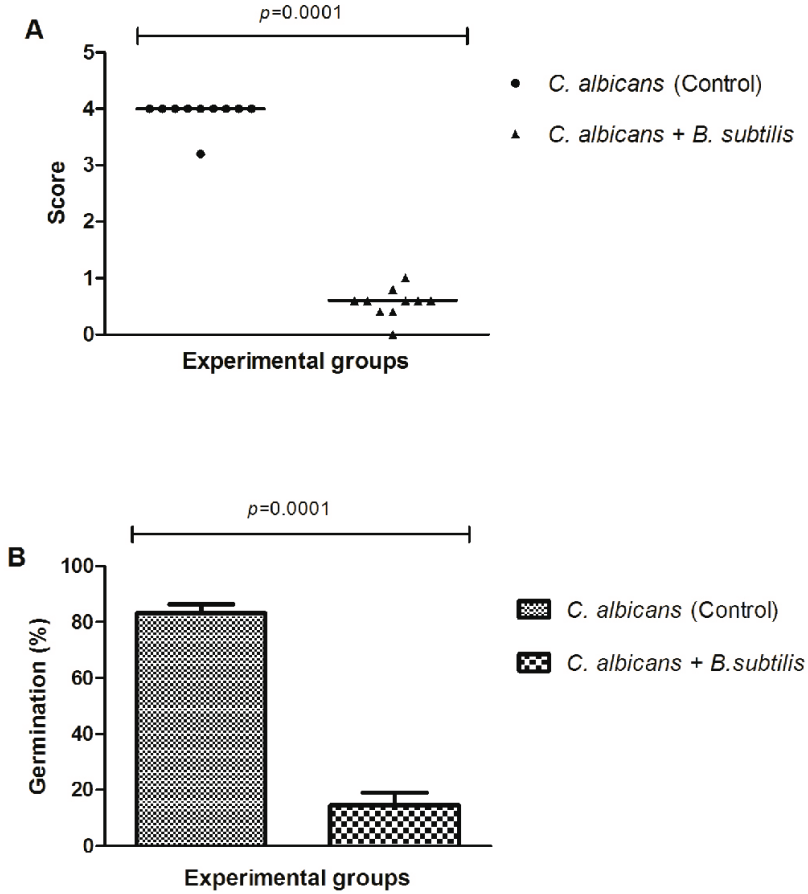

Figure 2 - Bacillus subtilis reduce C. albicans filamentation. (A): Median scores obtained by determining the number of hyphae in the in vitro Candida, filamentation assay for the following groups: $C$. albicans control group, interaction group with $B$ subtilis. A significant hyphal reduction was observed in the interaction group compared to the control group (MannWhitney test, $p \leq 0.05$ ). (B) Percentage germination, expressed as the mean values of hyphae, in the viability of $C$. albicans when associated with $B$. subtilis.

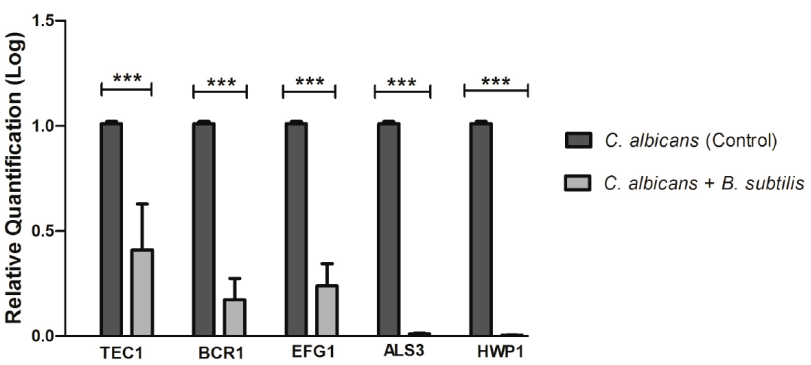

Figure $\mathbf{3}$ - Bacillus subtilis decreased the expression of $C$. albicans genes involved in biofilm formation. Relative quantification (Log) of TEC1, BCR1, EFG1, ALS3 and HWP1 genes in monotypic and mixed biofilms formed by C. albicans. The units in the $\mathrm{Y}$-axis were calculated based on the 2-DDCT method, and are expressed as the means and standard deviations. Each gene was normalized and compared with the expression of monotypic biofilms of C. albicans (control groups) using the reference gene RIP1. Student's $t$-test was used to compare gene expression between the groups ( $p \leq$ 0.05). ${ }^{* * *}$ indicates $\mathrm{p} \leq 0.0001$. 


\section{DISCUSSION}

Biofilm growth is a main model of microbial life and up to $80 \%$ of all microorganisms are sessile attached to the surface of biofilm communities. Within this group of microorganisms, 65 to $80 \%$ can cause microbial infections in humans from pathogenic biofilm formation [20]. The capability of biofilm formation and morphological transformation from yeast to hyphae are important to $C$. albicans pathogenicity [21]. Biofilms create an area of higher antimicrobial resistance for the residing microorganisms [20]. Thus, the interactions between bacteria and fungi can influence survival and proliferation, which can be beneficial for microorganisms because it increases resistance to antimicrobials or antagonistic that lead to death [22].

In this study, the results demonstrated that $C$. albicans was reduced in association with $B$. subtilis during biofilm formation. The quantification of $\mathrm{CFU} / \mathrm{mL}$ showed a reduction of $87.44 \%$ in C. albicans cells when compared to the control group. Thus, it demonstrated that in mixed biofilm the microorganisms interacted competitively and antagonistic, suggesting an inhibitory effect of $B$. subtilis on $C$. albicans. A possible explanation for the reduction of biofilm formation by $C$. albicans during the microbial interaction is the fact that Bacillus spp. secrete antimicrobial agents, such as bacteriocins, which have effects for suppressing the growth of competitive and opportunistic microorganisms $[8,9]$. One example is Subtilisin A, which is a bacteriocin isolated from B. subtilis [23]. $B$. subtilis in mixed biofilms did not present a significant reduction in relation to the monotypic biofilm. According to López et al. [24] B. subtilis uses a mechanism called cannibalism to slow its sporulation, and these cannibal cells secrete two toxins, skf and sdp, in which they can interfere with the growth of other microorganisms, constituting as a defense mechanism of $B$. subtilis.

Furthermore, we analyzed hyphae formation in C. albicans, and the results showed a significant reduction in the number of hyphae when compared to the control group of $C$. albicans, which confirms the results previously obtained by the inhibitory effect exerted by $B$. subtilis on $C$. albicans biofilm. Ability of Candida to reversibly switch between budding yeast and filamentous form is crucial for establishing infection. This phenotypic plasticity is tightly regulated by several environmental cues and internal signaling pathways [25]. The hyphal formation is related to gene expression that encodes virulence factors, such as the hyphae wall proteins HWP1 and ALS3 [25].

To confirm the results obtained in the CFU/ $\mathrm{mL}$ and filamentation assays, we analyzed the expression of ALS3, HWP1, BCR1, EFG1 and TEC1, which are $C$. albicans virulence genes responsible for biofilm formation and morphogenesis of yeast, by the relative quantification method qPCR [21,25]. All of these genes were significantly downregulated compared to monotypic biofilms, demonstrating the reduction effect of $B$. subtilis on morphogenesis and biofilm formation in C. albicans. HWP 1 and $A L S 3$ were the most downregulated genes in the presence of $B$. subtilis, and this result can be associated with the decrease in the CFU counts, the hyphae formation interfering in biofilm formation. Our findings are in agreement with Rautela et al. [8] that evaluated the influence of cyclic lipopeptides, fengycin and iturin, produced by Bacillus amyloliquefaciens strain AR2 in C. albicans biofilms. They showed that the fungicidal activity was concentration dependent and sub-minimal concentrations of the lipopeptide showed a decrease in the hydrophobicity of the cell surface, formation of germinative tubes and reduced of the hyphae specific genes, such as HWP1 and ALS3.

Our results show the potential antifungal effect of $B$. subtilis, since this species interferes in the transcriptional analysis of C. albicans. Recently, Subramenium et al. [26] evaluated the antibiofilm effect of $B$. subtilis, a marine bacterial isolate from Palk Bay against $C$. albicans. This bacterium was able to reduce the biofilm of $C$. albicans by up to $90 \%$, the filamentation and 
production of hydrolytic enzymes. In addition, the genes ERG11, FLU1, CDR2 and CDR1 (involved in drug resistance mechanisms) were downregulated when associated with $B$. subtilis.

The interactions between bacteria and fungi are highly complex and many factors need to be analyzed together, such as microorganism virulence associated with environmental factors and interactions between different species of microorganisms present in certain niches, requiring proper development of in vitro and in vivo models to characterize these interactions. The results from the experimental conditions described in this study demonstrated that $B$. subtilis inhibited $C$. albicans, suggesting that this bacterium produced compounds and/or metabolites with antifungal activity.

\section{CONCLUSION}

In conclusion, this study demonstrated that $B$. subtilis reduced the biofilm formation and filamentation of $C$. albicans by negatively regulating the $A L S 3, H W P 1, B C R 1, E F G 1$ and TEC1 genes that are essential for the production of biofilm and hyphae.

\section{ACKNOWLEDGEMENTS}

This study was supported by the São Paulo Council of Research - FAPESP, Brazil (Grants 2012/15250-0, 2013/25181-8 and 2015/09770-9) for supporting this research.

\section{REFERENCES}

1. Ganguly S, Mitchell AP. Mucosal biofilms of Candida albicans. Curr Opin Microbiol.2011;14:380-385. doi:10.1016/j.mib.2011.06.001.

2. Ramage G, Mowat E, Jones B, Williams C, Lopez-Ribot J. Our current understanding of fungal biofilms. Crit Rev Microbiol.2009;35:340-355. doi:10.3109/10408410903241436.

3. Chevalier M, Ranque S, Precheur I. Oral fungal-bacterial biofilm models in vitro: a review. Med Mycol.2018;56:653-667.doi:10.1093/mmy/myx111.

4. Bink A, Govaert G, Vandenbosch D, Kucharikova S, Coenye T, Nelis H, Thevissen K. Transcription factor Efg1 contributes to the tolerance of Candida albicans biofilms against antifungal agents in vitro and in vivo. J Med Microbiol.2012;61:813-819.doi: 10.1099/jmm.0.041020-0.
5. Lohse MB, Gulati M, Johnson AD, Nobile CJ. Development and regulation of single- and multi-species Candida albicans biofilms. Nat Rev Microbiol.2018;16:19-31.doi: 10.1038/nrmicro.2017.107

6. Onishi J, Meinz M, Thompson J, Curotto J, Dreikorn S, Rosenbach $M$, et al. Discovery of novelantifungal $(1,3)$-beta-D-glucan synthase inhibitors. Antimicrob Agents Chemother. 2000;44:368-377. PMC89685.

7. Zhang X, Jacob MR, Rao RR, Wang YH, Agarwal AK, Newman DJ, Khan IA, Clark AM, Li XC. Antifungal cyclicpeptides from the marine sponge. Res Rep Med Chem.2012;2:7-14.doi:10.2147/RRMC.S30895.

8. Rautela R, Singh AK, Shukla A, Cameotra SS. Lipopeptides from Bacillus strain AR2 inhibits biofilm formation by Candida albicans. Antonie Van Leeuwenhoek.2014;105:809-821.doi: 10.1007/s10482-0140135-2.

9. Sella SR, Vandenberghe LP, Soccol CR. Bacillus atrophaeus: main characteristics and biotechnological applications - a review. Crit Rev Biotechnol.2015;35:533-45.doi:10.3109/07388551.2014.922915.

10. Pinchuk IV, Bressollier P, Verneuil B, Fenet B, Sorokulova IB, Megraud $\mathrm{F}$, Urdaci MC. In vitro anti-Helicobacter pyloriactivity of the probiotic strain Bacillus subtilis 3 is due to secretion of antibiotics. Antimicrob Agents Chemother. 2001;45:3156-3161.doi:10.1128/AAC.45.11.31563161.2001.

11. Zheng G, Slavik MF. Isolation, partial purification and characterization of a bacteriocin produced by a newly isolated Bacillus subtilis strain. Lett Appl Microbiol.1999;28:363-7. PMID:10347890.

12. Cladera-Olivera F, Caron GR, Brandelli A. Bacteriocin like substance production by Bacillus licheniformis strain P40. Lett Appl Microbiol. 2004;38:251-6. PMID:15214721.

13. Mayer FL, Kronstad JW. Breaking the bad: Bacillus blocks fungal virulence factors. Microb Cell.2017;30:384-6. doi: 10.15698/ mic2017.11.599.

14. Seneviratne CJ, Silva WJ, Jin LJ, Samaranayake YH, Samaranayake LP. Architectural analysis, viability assessment and growth kinetics of Candida albicans and Candida glabratabiofilms. Arch Oral Biol. 2009;54:1052-1060.doi:10.1016/j.archoralbio.2009.08.002.

15. Bridier A, Sanchez-Vizuete Mdel P, Le Coq D, Aymerich S, Meylheuc T, Maillard JY, Briandet R. Biofilms of a Bacillus subtilis hospital isolate protect Staphylococcus aureus from biocide action. PLoS One.2012;7: e44506.doi: 10.1371/journal.pone.0044506.

16. Ribeiro FC, de Barros PP, Rossoni RD, Junqueira JC, Jorge AOC. Lactobacillus rhamnosus inhibits Candida albicans virulence factors in vitro and modulates immune system in Galleria mellonella. J Appl Microbiol. 2017;122:201-211.doi: 10.1111/jam.13324.

17. de Barros PP, Rossoni RD, Freire F, Ribeiro FC, Lopes L, Junqueira $\mathrm{JC}$, Jorge AOC. Candida tropicalis affects the virulence profile of Candida albicans: an in vitro and in vivo study. Pathog Dis. 2018;76:2 doi:10.1093/femspd/fty014.

18. Nailis H, Kucharikova S, Ricicova M, Van Dijck P, Deforce D, Nelis H, Coenye T. Real-time PCR expression profiling of genes encoding potential virulence factors in Candida albicans biofilms: identification of model-dependent and -independent gene expression. BMC Microbiol. 2010;10:114. doi:10.1186/1471-2180-10-114.

19. Livak KJ, Schmittgen TD. Analysis of relative gene expression data using real-time quantitative PCR and the 2(-Delta Delta C(T)) Method. Methods.2001;25:402-408.doi:10.1006/meth.2001.1262. 
20. Bonhomme J, d'Enfert C. Candida albicans biofilms: building a heterogeneous, drug-tolerant environment. Curr Opin Microbiol.2013;16:398-403.doi: 10.1016/j.mib.2013.03.007.

21. 21. Mayer FL, Wilson D, Hube B. Candida albicans pathogenicity mechanisms. Virulence. 2013;4:119-128. doi: 10.4161/viru.22913.

22. 22- Peleg AY, Hogan DA, Mylonakis E. Medically important bacterialfungal interactions. Nat Rev Microbiol. 2010;8:340-349. doi: 10.1038/ nrmicro2313.

23. 23. Sutyak KE, Wirawan RE, Aroutcheva AA, Chikindas ML. Isolation of the Bacillus subtilis antimicrobial peptide subtilosin from the dairy product-derived Bacillus amyloliquefaciens. J Appl Microbiol. 2008;104:1067-1074.doi:10.1111/j.1365-2672.2007.03626.x
24. 24. Lopez D, Vlamakis H, Losick R, Kolter R. Cannibalism enhances biofilm development in Bacillus subtilis. Mol Microbiol. 2009;74:609618.doi:10.1111/j.1365-2958.2009.06882.

25. 25. Tsang PW, Bandara HM, Fong WP. Purpurin suppresses Candida albicans biofilm formation and hyphal development. PLoS One. 2012;7:e50866.doi: 10.1371/journal.pone.0050866.

26. 26. Subramenium GA, Swetha TK, Iyer PM, Balamurugan K, Pandian SK. 5-hydroxymethyl-2-furaldehyde from marine bacterium Bacillus subtilis inhibits biofilm and virulence of Candida albicans. Microbiol Res. 2018:207:19-32. doi: 10.1016/j.micres.2017.11.002.

\section{Patrícia Pimentel de Barros}

(Corresponding address)

Department of Biosciences and Oral Diagnosis

Univ Estadual Paulista/UNESP

Av. Eng Francisco José Longo 777, São Dimas, São José dos Campos

CEP: 12245-000, SP, Brazil.

E-mail: barrosdnapp@yahoo.com.br

Date submitted: 2018 Nov 13

Accept submission: 2019 Feb 26 